\author{
S. Haievskyi ${ }^{1}$, S. Hmelevskyi ${ }^{2}$, A. Boyko ${ }^{3}$, T. Myschenko ${ }^{4}$, O. Timochko ${ }^{5}$ \\ ${ }^{1}$ Flight Academy of the National Aviation University, Kropyvnytskyi, Ukraine \\ ${ }^{2}$ I. Kozhedub Kharkiv National University of the Air Force, Kharkiv, Ukraine \\ ${ }^{3}$ Military unit A3544, Kropyvnytskyi, Ukraine \\ ${ }^{4}$ Military unit A2171, Odesa, Ukraine \\ ${ }^{5}$ Company "Kreditech", Hamburg, Germany
}

\title{
MATHEMATICAL MODELS OF THE FAILURE FLOW OF THE AIRCRAFT ELECTRONIC SYSTEM COMPONENTS
}

\begin{abstract}
The subject of the article is the process of functioning of the modern aircraft electronic system, its components and functional units as an object of mathematical model. The purpose is to analyze an existing mathematical apparatus, which is used to calculate the failure flow of the plane radio-electronic system and opportunities for its improvement. Tasks: to build mathematical models of the failure flow of components, functional units and the plane radioelectronic system as a whole with an unlimited number of recoveries with different depth of resource recovery. The analyzed methods are: parametric methods and probabilistic methods for assessment failureless. The results obtained: mathematical models of the failure flow of the circuit positions of the aircraft electronic system were developed. Conclusions. A generalization of the well-known mathematical models of the failure flow with an unlimited number of minimum restorations of finite duration is obtained as a result of consideration of mathematical models of the failure flow of the circuit positions of the plane radio-electronic system.
\end{abstract}

Keywords : residual resource, airplane; mathematical model; failure flow; aircraft electronic system; technical condition; circuit position.

\section{Introduction}

Formulation of the problem in general. Scientific and technological progress has led to the improvement of the element base, a significant change in the nature of the operation and maintenance of the modern aircraft electronic systems (AES).

Microelectronic components are the basis of modern avionics. Digital technologies with a high degree of integration make it difficult to use the existing scientific and methodological apparatus for assessing AES failures. The reason for this is the production of rough and overvalued forecasts of the failureless of the aircraft electronic system. These facts necessitate a critical analysis of well-known models for assessing failures and calculating the indicators of the residual resource of aircraft electronic system and its components.

The purpose of the analysis is to assess the residual resource and to extend the assigned time life while maintaining appropriate performance indicators [1].

Analysis of the References. Currently, the introduction of modern element base into radio-electronic equipment is not fully taken into account [2-6].

The widespread use of microelectronic components leads to dramatic changes in the failure flow in electronic systems.

Known mathematical models for assessing the reliability and failureless do not allow to obtain adequate results [5-12].

Accordingly, it is necessary to improve the existing scientific and methodological apparatus used to simulate the failure flow (failureless) of circuit positions (components, functional units and systems) of the aircraft radio-electronic system.

The aim of the article is to develop mathematical models of the failure flow of the circuit positions of the plane radio-electronic system.

\section{Main part}

Mathematical models of the failure flow of the aircraft's AES components with an unlimited number of recoveries of different depths. In the general case, in the restored object, the replacement of the failed element is made by serviceable elements that have lost a certain technical resource. The literature [13] shows the relationship between the failure flow parameter and the distribution density of the time between failures for the case of an unlimited number of full recoveries. The failure flow parameter with an unlimited number of full recoveries is most fully investigated in the monograph [14]. In [15], the dependence of the failure flow parameter on the density of the distribution of the time between failures with an unlimited number of minimum recoveries was obtained. For this case, it has been shown analytically and experimentally confirmed that the failure flow parameter coincides with the failure intensity [16]. In the case of complete recoveries, the integral equation obtained in [8] follows from the integral equation obtained in [14]. Naturally, both assumptions about the state of replacement elements before they are used are extreme. They can serve to find the lower and upper bounds on the reliability estimates of elements and systems. For long-term operation, these boundaries are quite wide and, therefore, the accuracy of calculating reliability indicators is low.

Following [16], we obtain an expression for the failure flow parameter when replacement elements have spent a certain technical resource.

Let the elements of certain circuit positions (main) are in the mode $\varepsilon$; replacement elements (spare) are in the mode $\varepsilon_{p}$. Then the conditional probability of failure-free operation of the replaced (restored) element during the time $t-\tau$ in the mode $\varepsilon$, provided that the 
element is in the mode $\varepsilon_{p}$ for replacement and has not failed for the time $\tau$, can be written as:

$$
\begin{gathered}
P_{B}=\left(t-\tau, \varepsilon / \tau, \varepsilon_{p}\right)= \\
=P(t-\tau+x(\tau), \varepsilon) / P(x(\tau), \varepsilon),
\end{gathered}
$$

where $x(\tau)$ is the operating time of the element in the mode $\varepsilon$, equivalent to its operating time $\tau$ in the mode $\varepsilon_{p}$, provided that the resources they spent in these modes are the same (or $x(\tau)$ is the value of the spent resource of the element in the mode $\varepsilon$ ).

Relation (1) is correct if the failureless of the replacement elements after setting them in the mode $\varepsilon$ does not depend on how the resource was spent, but depends only on the amount of the spent resource in the past. Physically, this means that in the materials of the elements there were no qualitative changes in the properties when working in the modes $\varepsilon$ and $\varepsilon_{p}$.

Note that the value $x(\tau)$ can be found from the condition of equal resources in accordance with the Sedyakin principle (or other principles known in the scientific and technical literature)

$$
\int_{0}^{x(\tau)} \lambda(z, \varepsilon) d z=\int_{0}^{\tau} \lambda\left(z, \varepsilon_{p}\right) d z .
$$

We find the conditional distribution density of the operating time of the element to failure, taking the derivative according to $t$ the expression (1):

$$
f_{B}\left(t-\tau, \varepsilon / \tau, \varepsilon_{p}\right)=f(t-\tau,+x(\tau), \varepsilon) / P(x(\tau), \varepsilon) .
$$

Then, substituting the found distribution density in the Volterra equation, we obtain:

$$
\omega(t)=f(t, \varepsilon)+\int_{0}^{t} \frac{f(t-\tau+x(\tau), \varepsilon)}{P(x(\tau), \varepsilon)} \omega(\tau) d \tau .
$$

We now consider individual cases that follow from (3).

1. A case of complete recovery, that is, the replacement of failed elements is carried out by new ones. Then $x(\tau)=0 ; P(x(\tau), \varepsilon)=1$, and from (3) follows the well-known formula:

$$
\omega_{1}(t)=f(t, \varepsilon)+\int_{0}^{t} f(t-\tau, \varepsilon) \omega_{1}(\tau) d \tau .
$$

2. The case of minimal updates, that is, the replacement of failed elements is carried out by workable elements that have developed the same resource as the main elements. Then $x(\tau)=\tau, P(x(\tau), \varepsilon)=P(\tau)$ and from (3) the integral equation follows

$$
\omega_{2}(t)=f(t)\left[1+\int_{0}^{t} \frac{\omega_{2}(\tau)}{P(\tau)} d \tau\right] .
$$

We now prove that (5) implies the equality

$$
\omega_{2}(t)=\lambda(t) \text {, }
$$

that is, the failure flow parameter with minimal recovery is equal to the failure rate.

Equality (6) is obtained by differentiating expression (5) by $t$ :

$$
\omega_{2}^{\prime}(t)=f^{\prime}(t)+f^{\prime}(t) \int_{0}^{t} \frac{\omega_{2}(\tau)}{P(\tau)} d \tau+f(t) \frac{\omega_{2}(\tau)}{P(\tau)} .
$$

It follows from (5) that

$$
\int_{0}^{t} \frac{\omega_{2}(\tau)}{P(t)}=\frac{\omega_{2}(t)}{f(t)}-1 .
$$

Substituting (8) into (7), we obtain

$$
\omega_{2}^{\prime}(t)-\left(\lambda^{\prime}(t) / \lambda(t)\right) \cdot \omega_{2}(t)=0 .
$$

The solution of this homogeneous differential equation has the form:

$$
\omega_{2}(t)=c \lambda(t) .
$$

The integration constant is as follows. From equation (8) and the obvious

$$
\lambda(0)=f(0) / P(0)=f(0)
$$

it follows

$$
\omega_{2}(0)=f(0)=\lambda(0)=c \lambda(0),
$$

that is $c=1$. So, $\omega_{2}(t)=\lambda(t)$.

We examined the case of instantaneous recovery. With non-instantaneous incomplete recovery, it can be shown that the following relation holds for the failure flow parameter:

$$
\begin{gathered}
\omega_{2}(t)=f(t)+ \\
+\int_{0}^{t} \omega(\tau) \int_{0}^{t-\tau} \frac{g(\eta) f(t-\tau-\eta+x(t+\eta))}{P(x(\tau+\eta))} d \eta d \tau
\end{gathered}
$$

where $g(t)$ is the density of the distribution of the recovery time of the failed element.

We consider individual cases for noninstantaneous incomplete recovery arising from (9).

1. The case of complete recovery. Then $x(\tau+\eta)=0 ; \quad P(x(\tau+\eta))=P(\tau+\eta)$ and from (9) follows:

$$
\omega_{1}(t)=f(t)+\int_{0}^{t} \omega_{1}(\tau) \int_{0}^{t-\tau} g(\eta) f(t-\tau-\eta) d \eta d \tau .
$$

2. The case of minimal recoveries. The case of minimal updates. Then

$$
x(\tau+\eta)=(\tau+\eta) ; P(x(\tau+\eta))=1
$$

and from (9) follows:

$$
\omega_{2}(t)=f(t) \cdot\left[1+\int_{0}^{t} \omega_{2}(\tau) \int_{0}^{t-\tau} \frac{g(\eta)}{P(\tau+\eta)} d \eta d \tau\right] .
$$

In [14], for the exponential law of the distribution of the recovery time $g(\eta)=\mu e^{-\mu \eta}$, the following expression was obtained for the failure flow parameter: 


$$
\begin{gathered}
\omega_{2}(t)=\lambda(t) \exp \left\{-\int_{0}^{t}[\lambda(z)+\mu] d z\right\} \times \\
\times\left[1+\mu \int_{0}^{t} \exp \left\{\int_{0}^{z}[\lambda(x)+\mu] d x\right\} d z\right]
\end{gathered}
$$

Note that with the exponential law of the distribution of the time between failures, equation (4) coincides with equation (5), and equation (10) coincides with equation (11). In this case, with instantaneous recovery $\omega_{1}(t)=\omega_{2}(t)=\lambda$ and

$$
\omega_{1}(t)=\omega_{2}(t)=\lambda\left(\frac{\mu}{\lambda+\mu}+\frac{\lambda}{\lambda+\mu} e^{-(\lambda+\mu) t}\right)
$$

with non-instantaneous recovery.

At an exponential distribution density of the recovery time, the expression in parentheses is an unsteady availability factor $K_{2}(t)$. It is obtained under the condition that at the time $t=0$ the element is operational, that is at $K_{2}(0)=1$. From formula (13) it can be seen that the parameter of the failure flow at the moment is

$$
\omega_{1}(t)=\lambda K_{2}(t)
$$

failure rate multiplied by the probability that the element is in a working condition at a given time $t$.

From (14) find the stationary value $\omega_{1}(t)$

$$
\lim _{n \rightarrow \infty} \omega_{1}(t)=\lambda K_{2}
$$

that is, with the exponential laws of the distribution of uptime and recovery time, the failure flow parameter decreases from the value $\omega_{1}(0)=\lambda$ and tends to a constant value equal to $\lambda K_{2}$. Moreover, the longer the average recovery time, the smaller the value of the failure flow parameter. This is due to the fact that when restoring the device, the element to be replaced does not function and does not consume its resource. The effect of reducing the total operating time of an element for a fixed time is created.

Now we obtain a generalization of the result (12) for the case when the law of distribution of the recovery time differs from the exponential one and is characterized by the recovery intensity $\mu(t)$. In this case, the elements at a time $t=0$ are in working condition with probability $\gamma$. If the element is in an operational state at the moment $t$, then its failure-free operation is characterized by the failure rate $\lambda(t)$ and does not depend on the number of failures that occurred before the time $t$, and the length of time since the last recovery. The behavior of such an element in the device can be described by the following system of differential equations

$$
\left.\begin{array}{l}
P_{0}^{\prime}(t)=-\lambda(t) P_{0}(t)+\mu(t) P_{1}(t), \\
P_{1}^{\prime}(t)=\lambda(t) P_{0}(t)-\mu(t) P_{1}(t),
\end{array}\right\},
$$

where $P_{0}(t), P_{1}(t)$ are the probabilities of finding an element, respectively, in a working and non-working states. The solution to this system, taking into account the normalization condition $P_{0}(t)+P_{1}(t)=1$ and the initial condition $P_{0}(t)=\gamma$, is

$$
K_{2}(t)=P_{0}(t)=e^{-F(t)}\left\{\gamma+\int_{0}^{t} \mu(z) e^{F(z)} d z\right\},
$$

where

$$
F(t)=\int_{0}^{t}\{\lambda(z)+\mu(z)\} d z .
$$

Then the element failure flow parameter will be found as the multiplication of the element failure rate at the moment $t$ and the unsteady availability factor, namely

$$
\omega_{2}(t)=\lambda(t) K_{2}(t) .
$$

Relations (16)-(18) are a generalization of previously considered models with non-instantaneous recovery. So, in particular, result (12) is a special case from (16)-(18) when substituting the recovery intensities $\mu(t)=\mu$ in them for the exponential distribution density and the initial condition $K_{2}(0)=\gamma=1$, and result (13) - when substituting $\lambda(t)=\lambda, \mu(t)=\mu$, and $\gamma=1$.

Thus, various mathematical models of the failure flow of renewable elements with an unlimited number of instantaneous and finite recovery times with different resource recovery depths are considered. A generalized failure flow model with incomplete recoveries is obtained. Failure flow models with full and minimum recoveries arising from a model with incomplete recoveries, as special cases under the appropriate conditions in which replacement elements are located.

A more general expression is obtained for the failure flow parameter with minimal non-instantaneous updates than previously known.

Failure flow models with full and minimal recoveries can be used to calculate the upper and lower estimates of the real reliability of the systems depending on the nature of the restoration. So, if in the process of system recovery most of the elements are replaced with new ones, then models with full restorations are used. If during the restoration only a single defective element or any functional unit (PV) or part of a functional system (FS) is replaced by a working one that has the same operating time as the replaced element, then it is acceptable to use models with minimal recovery. However, for solving problems investigating the longterm operation of systems, such boundaries are wide enough, and the accuracy of estimating the parameter of the failure flow may be low. In this case, models with incomplete restorations must be used.

The considered mathematical models of the flow of failures should be used in assessing the reliability indicators of devices according to the failure statistics of recovered systems. From the failure statistics, you can get direct values of the failure flow parameter $\omega(\mathrm{t})$. After that, knowing the nature of system recoveries during operation and using appropriate models with 
minimal, incomplete, or full recoveries, one can obtain estimates of the failure rate $\lambda(t)$, or distribution density of duration of failure-free operation.

Mathematical models of the failure flow of AES components with a limited number of restorations of different depths. The vast majority of the circuit positions of the AES during the designated service life does not fail. A significant part of the elements fails one to two times, an even smaller part - three to four times, etc. [17]. Replacing a failed (defective) component of a specific circuit position of the AES can be carried out by a new component, recovered component or component, which has spent part of its resource. Therefore, it is necessary to develop models of failure flows with a limited number of recoveries (replacements) and different depths of the recovered resource. As in the case of an unlimited number of recoveries, we first consider mathematical models of the failure flow with a limited number of instantaneous recoveries, and then models with a limited number of non-instantaneous recoveries.

Mathematical model of the failure flow of a component circuit position with a finite number of complete instantaneous restorations.

The recovery theory shows that the failure flow parameter of an element with complete recoveries is characterized by a series

$$
\omega_{1}(t)=\sum_{k=1}^{\infty} f_{k}(t)
$$

where $f_{k}(t)$ is the density of the distribution of the value of the component operating time to $k$-th failure $x_{k}=\sum_{i=1}^{k} \xi_{i}, \quad k \geq 1 ; \quad \xi_{i}$ is random of component operation after $(i-1)$-th recovery.

In the case of complete recoveries, the distribution density of the value $x_{k}(t)$ is as $k$-multiple convolution of the density of random variables $\xi_{i}$ :

$$
f_{k}(t)=f_{k-1}(t) * f_{1}(t) .
$$

The number of recoveries $n(t)$ during the assigned service life (or assigned resource) is expected to be known. It is due either to the component ultimate failure, or technical and other restrictions on the number of recoveries. With a known number of complete recoveries $n(t)$ the considered operating time, the failure flow parameter is determined by the expression

$$
\omega_{1}(t)=\sum_{k=1}^{n(t)} f_{k}(t)
$$

So, for normal distribution

$$
\begin{gathered}
f_{k}(t)=(-\sqrt{2 \pi k} \sigma)^{-1} \exp \left[-\frac{\left(t-k T_{0}\right)^{2}}{2 k \sigma^{2}}\right] \\
\omega_{1}(t)=\sum_{k=1}^{n(t)}(\sqrt{2 \pi k} \sigma)^{-1} \exp \left[-\frac{\left(t-k T_{0}\right)^{2}}{2 k \sigma^{2}}\right] .
\end{gathered}
$$$$
\text { and }
$$

For exponential distribution

$$
\begin{gathered}
f_{k}(t)=\lambda \frac{(\lambda t)^{k-1}}{(k-1) !} e^{(-\lambda t)} \\
\omega_{1}(t)=\sum_{k=1}^{n(t)} \lambda \frac{(\lambda t)^{k-1}}{(k-1) !} e^{(-\lambda t)} .
\end{gathered}
$$

For the Erlang distribution of the $m$-th order

$$
\omega_{1}(t)=\sum_{k=1}^{n(t)} \lambda \frac{(\lambda t)^{m k-1}}{(m k-1) !} e^{(-\lambda t)} .
$$

Convolution calculation $f_{k}(t)$ is an easily feasible operation for a limited number of distributions, such as a normal, exponential, gamma distribution.

Let us now consider a mathematical model of the failure flow with a finite number of instantaneous minimum recoveries.

It is known that the process of recovery of FS AES at intervals between full resource recoveries is characterized, as a rule, minimal recoveries. At the minimum recoveries the densities of distribution of size of operating time to $k$-th minimum recoveries are various. Based on the fact that the density distribution of the value $X_{k}$ is random, the operating time of the circuit position to the $k$-th minimum instantaneous recovery is determined by the expression

$$
f_{k}^{(2)}(t)=\lambda(t) \frac{(\Lambda(t))^{k-1}}{(k-1) !} \exp [-\Lambda(t)]
$$

where

$$
\Lambda(t)=\int_{0}^{t} \lambda(x) d x .
$$

Since the density distribution of the value of random operating time before the first failure

$$
\begin{gathered}
f(t)=\lambda(t) \exp [-\Lambda(t)], \\
f_{k}^{(2)}(t)=\frac{(\Lambda(t))^{k-1}}{(k-1) !}-f(t) .
\end{gathered}
$$

Then the failure flow parameter for the finite number $n(t)$ of minimum instantaneous recoveries can be found by relation (20):

$$
\omega_{2}(t)=\sum_{k=1}^{n(t)} f_{k}^{(2)}(t)=f(t) \sum_{k=1}^{n(t)} \frac{[\Lambda(t)]^{k-1}}{(k-1) !} .
$$

Relation (22) for $n(t) \rightarrow \infty$ can be written as:

$$
\omega_{2}(t)=\lambda(t) \exp [-\Lambda(t)] \sum_{k=1}^{\infty} \frac{[\Lambda(t)]^{k-1}}{(k-1) !} .
$$

Note that in the case of an unlimited number of minimum recoveries for $n \rightarrow \infty$, the failure flow parameter is equal to the failure rate

$$
\omega_{2}(t)=\lambda(t) \exp [-\Lambda(t)] \sum_{k=1}^{\infty}[-\Lambda(t)]^{k} / k !=\lambda(t) .
$$


This corresponds to the result (6) discussed above. Therefore, the correctness of the obtained result for the mathematical model of the failure flow with a finite number of instantaneous minimum recoveries is confirmed. Here are the main calculated relations for different densities of time distribution:

$$
\begin{array}{r}
\text { a) } f(t)=c(\sqrt{2 \pi} \sigma)^{-1} \exp \left[-\left(t-T_{0}\right)^{2} /\left(2 \sigma^{2}\right)\right] ; \\
c=\left[\Phi\left(T_{0} / \sigma\right)\right]^{-1} . \\
\lambda(t)=(\sqrt{2 \pi} \sigma)^{-1}\left[\Phi\left(\frac{T_{0}-t}{\sigma}\right)\right] \exp \left[-\frac{\left(t-T_{0}\right)^{2}}{2 \sigma^{2}}\right] .
\end{array}
$$

The calculation of the characteristic is connected with the integration of expression (24), which should be carried out by the numerical method;

б) $f(t)=\lambda(\lambda t) e^{(-\lambda t)} ; \lambda(t)=\lambda \cdot(\lambda t /(1+\lambda t))$.

Then $\Lambda(t)=\int_{0}^{t} \lambda \frac{\lambda t}{1+\lambda t} d t-\int_{0}^{\lambda t} \frac{v d v}{1+v}=\lambda t-\ln (1+\lambda t)$.

Using expression (20), we obtain

$$
\begin{gathered}
\omega_{2}(t)=\lambda(t) \times \\
\times \exp [-\lambda(t)] \sum_{k=1}^{n(t)}[\lambda(t)-\ln (1+\lambda(t))]^{k-1} /(k-1) ! .
\end{gathered}
$$

Consider a mathematical model of the failure flow with a finite number of instantaneous incomplete recoveries.

Above was introduced the concept of a complex recovery process. It is characterized by different densities of the distribution of the values of the operation before the first and between subsequent failures $f_{k-1, k}(t), k=1,2, \ldots, n(t)$. The density of the distribution of operation to $k$-th incomplete recovery is characterized by $k$-th convolution

$$
f_{k}^{(3)}(t)=f_{0,1}(t) * f_{1,2}(t) * \ldots * f_{k-1, k}(t) .
$$

In turn, the failure flow parameter for instantaneous incomplete recoveries is found by the ratio

$$
\omega_{3}(t)=\sum_{k=1}^{n} f_{k}^{(3)}(t) .
$$

Note that when predicting the component failure flow parameter of a certain circuit position, different variants of the description of the distribution density $f_{k-1, k}(t)$ are possible. They are determined by the nature of the recoveries of the defective component, the replacement strategy and other factors.

Thus, the operating time of a certain schematic position before the first failure $f_{0,1}(t)$ can be distributed according to the normal law, and between failures according to the Weibull distribution. Or the operating time before the first failure and between subsequent failures obey to a normal distribution with different values of mathematical expectation and standard deviation. If the operating time of the circuit position before the first failure and between subsequent failures obey the normal distribution with the parameters $T_{i}$ and $\sigma_{i}$, then the density of time distributions to the $k$-th failure will look like

$$
\begin{gathered}
f_{k}^{(3)}(t)=\left(2 \pi \sum_{i=1}^{k} \sigma^{2}\right)^{-1 / 2} \times \\
\times \exp \left\{-\left(t-\sum_{i=1}^{k} T\right)^{2} /\left(2 \sum_{i=1}^{k} \sigma^{2}\right)\right\} .
\end{gathered}
$$

The derivation of expression (27) is based on the fact that the sum of normally distributed random variables obey to the normal distribution. Then the failure flow parameter with a finite number of instantaneous incomplete recoveries has the form described by the model of a complex recovery process:

$$
\begin{gathered}
\omega_{3}(t)=\sum_{k=1}^{n(t)}\left(2 \pi \sum_{i=1}^{k} \sigma^{2}\right)^{-1 / 2} \times \\
\times \exp \left\{-\left(t-\sum_{i=1}^{k} T\right)^{2} /\left(2 \sum_{i=1}^{k} \sigma^{2}\right)\right\} .
\end{gathered}
$$

From expression (28) we can obtain ratios for simple and general recovery processes as individual cases of complex.

If the operating time of a certain circuit position before the first failure and between subsequent failures are described by an exponential law with parameters $\lambda_{i}$, then the density distribution of the operating time $k$-th failure is a generalized Erlang's law of the $k$-th order

$$
\begin{gathered}
f_{k}^{(3)}(t)=(-l)^{k-1} \times \\
\times \prod_{i=1}^{k} \lambda_{i} \sum_{j=1}^{k} \exp \left(-\lambda_{j} t\right) / \prod_{l=1(l \neq j)}^{k}\left(\lambda_{j}-\lambda_{l}\right) .
\end{gathered}
$$

Then the failure flow parameter with a finite number of instantaneous incomplete recoveries has the form

$$
\begin{gathered}
\omega_{k}^{(3)}(t)=\sum_{k=1}^{n(t)}(-l)^{k-1} \times \\
\times \prod_{i=1}^{k} \lambda_{i} \sum_{j=1}^{k} \exp \left(-\lambda_{j} t\right) / \prod_{l=1(l \neq j)}^{k}\left(\lambda_{j}-\lambda_{l}\right) .
\end{gathered}
$$

Now we present models of failure flow of the circuit position with a limited number of finite duration recoveries. First, consider a mathematical model of the failure flow with a limited number of complete recoveries of finite duration.

There are the following dependencies for the failures flow of the circuit position, the duration recovery of which can not be neglected (Fig. 1):

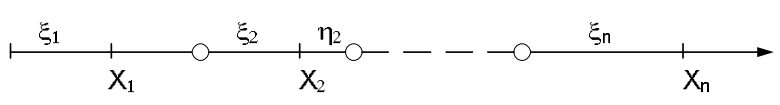

Fig. 1. Alternating process of failures (recoveries) with a limited number of recoveries 


$$
\begin{gathered}
\sum_{i=1}^{k} \sigma^{2} \quad X_{1}=\xi_{1}, X_{2}=\xi_{1}+\xi_{2}+\eta_{1}, \ldots, i=1,2, \ldots, n, \\
X_{i}=\sum_{l=1}^{i} \xi_{l}+\sum_{l=1}^{i-l} \eta_{l}, \text { that is } X_{i}=\sum_{l=1}^{i}\left(\xi_{l}+\eta_{l-1}\right),
\end{gathered}
$$

where $\eta_{0}=0, \eta_{l}$ is duration of $l$-th full recovery.

The values $\xi_{i}$ and $\eta_{i}$ are assumed by independent random variables with distribution functions $F(t)=P\left(\xi_{i}<t\right) \quad$ and $\quad G(t)=P\left(\eta_{i}<t\right) \quad$ with mathematical expectation $T_{O}, T_{B}$ and standard deviation $\sigma_{l}, \sigma_{b}$ with continuous densities of distribution of quantities $f(t)=F^{\prime}(t)$ and $g(t)=G^{\prime}(t)$.

The process defined in this way is called the recovery process with a final recovery time. You can write the following distribution functions for this process:

$$
\begin{gathered}
F_{k}(t)=P\left\{\sum_{i=1}^{k} \xi_{i}<t\right\} ; G_{k}(t)=P\left\{\sum_{i=1}^{k} \eta_{i}<t\right\} ; \\
\Phi_{k}(t)=P\left\{X_{k}<t\right\}
\end{gathered}
$$

and their distribution density

$$
f_{k}(t)=F_{k}^{\prime}(t) ; g_{k}(t)=G_{k}^{\prime}(t) ; \varphi_{k}(t)=\Phi_{k}^{\prime}(t) .
$$

These distribution functions are determined by the original laws $F(t)$ and $G(t)$ as follows

$$
\begin{aligned}
F_{k}(t) & =\int_{0}^{t} F_{k-l}(t-x) d F(x), F_{l}(t)=F(t), \\
G_{k}(t)= & \int_{0}^{t} G_{k-l}(t-x) d G(x), F_{l}(t)=F(t), \\
& \Phi_{k}(t)=\int_{0}^{t} F_{k}(t-x) d G_{k}(x) .
\end{aligned}
$$

Then the failure flow parameter of the circuit position with a finite number of complete noninstantaneous recoveries can be written as

$$
\omega_{1}(t)=\sum_{k=1}^{n(t)} \varphi_{k}(t) \text {. }
$$

We extend this result to the process of failure of the circuit position with a limited number of minimum recoveries of finite duration.

The failure flow of this process is characterized by the density distribution of a random variable $\sum_{i=1}^{k} \xi_{i}$ :

$$
f_{k}^{(2)}(t)=\frac{[\Lambda(t)]^{k-1}}{(k-1) !} f(t)
$$

and the flow of recoveries by the density distribution of a random variable $\sum_{i=1}^{k} \eta_{i}, g_{k}(t)=G_{k}^{\prime}(t)$.

The probability density distribution of a random variable $X_{k}, k=1,2, \ldots, n(t)$ is a convolution

$$
\varphi_{k}^{(2)}(t)=f_{k}^{(t)} * g_{k}(t) \text {. }
$$

Then the required ratio for the failure flow parameter has the form

$$
\omega_{2}(t)=\sum_{k=1}^{n(t)} \varphi_{k}^{(2)}(t) .
$$

Similarly, it is possible to expand the mathematical model of the failure flow with the limited number of complete recoveries for the process of the circuit position failure with the limited number of incomplete recoveries of finite duration.

The failures flow of the circuit position with incomplete recoveries of finite duration is characterized by the density of distribution of random variables $\sum_{i=1}^{k} \xi_{i} \sim f_{k}^{(3)}(t)$ and $\sum_{i=1}^{k} \eta_{i} \sim g_{k}(t)$. Then the distribution density of the random variable $X_{k}=\sum_{l=1}^{k}\left(\xi_{l}-\eta_{l-1}\right), \eta_{0} \equiv 0$ is a $k$-multiply convolution:

$$
\varphi_{k}^{(3)}(t)=f_{k}^{(3)}(t) * g_{k}(t)
$$

The failures flow (recoveries) parameter of this process is calculated by the ratio

$$
\omega^{(3)}(t)=\sum_{k=1}^{n(t)} \varphi_{k}^{(3)}(t)
$$

The presented rations (20), (26), (31)-(33) for calculation of failures flow parameter with limited number of recoveries of various depth are reduced to performance of operations of convolution. Convolution calculations are easy to perform for a limited number of typical random variable distributions. In the general case, the use of numerical methods is required.

The number of recoveries (or failures) $n(t)$ of components at a certain circuit position for the considered operation may be due to technical reasons, economic feasibility, safety and environmental performance requirements, the final failure. Below, we consider the estimation of the boundary number $n(t)$ of component's recoveries of a certain circuit position of AES for the assigned operating time (service life). Depending on the depth of recovery, the following options for estimating the value $n(t)$ are possible.

A. The case of complete recovery. It is known from the recovery theory that the number of failures $n(t)$ has an asymptotically normal distribution with mean $M n(t) \approx t / T_{0}$ and dispersion $D n(t) \approx \sigma^{2} t / T_{0}$ during $t>T_{0}$. The boundary number of failures (recoveries) can be selected so that

$$
P\left\{n(t) \leq n_{0}\right\}=\gamma .
$$

At large $t\left(t>>T_{0}\right)$ random variables $n(t)$ have an approximately normal distribution. Then for $n_{0}$ you can take the value $n_{0}=t / T_{0}+u_{l-\gamma} \sqrt{\sigma^{2} t / T^{3}}$, where $u_{l-\gamma}$ is the quantile of normal distribution. 
For small $t\left(t \geq T_{0}\right)$, or $t<T_{0}$ the boundary number of failures can be found from condition (34) by the method of convolutions. To do this, it is necessary to consistently find the function of the distribution of operating time to the first, second and largest number of failures to fulfill the condition (34)

B) The case of incomplete and minimal recoveries. We can assume that the function of distribution of operating time before failure belongs to the class of IIFdistributions. Recall that the distribution function $F(t)$ is called IIF-distribution, if the probability $\bar{F}(t+x) / \bar{F}(t)$ at an arbitrary constant $x \geq 0$ decreases monotonically by $t, 0<t<\infty$. The affiliation of the distribution function to the class of IIF-distributions is equivalent to the fact that the failure flow increases monotonically. Hence the name of the distribution class with an increasing failure intensity function.

It is known from the theory of recovery [7] that if the operating distribution function belongs to the class of IIF-distributions and has a mathematical expectation $T_{0}$, then

$$
P\left\{n(t)<n_{0}\right\} \leq \sum_{i=0}^{n_{0}-1} \frac{\left(t / T_{0}\right) !}{i !} e^{-t / T_{0}}, t<T_{0} .
$$

The estimate (35) is convenient for performing calculations, because to use it it is enough to know the mathematical expectation $T_{0}$. Another estimate for $t>0$ IIF-distributions is the following [7]:

$$
P\left\{n(t)<n_{0}\right\} \leq \sum_{i=0}^{n_{0}-1} \frac{(\Lambda(t))^{i}}{i !} e^{-\Lambda(t)}, t>0 .
$$

Since for each distribution function from the IIF class there is an inequality $\Lambda(t) \leq t / T_{0}$ for $t<T_{0}$, inequality (36) is a more precise boundary than (35). However, this requires an estimate of the mathematical expectation of the number of failures $\Lambda(t)$.

Thus, to estimate the boundary number of failures (recoveries) due to the final failure of the corresponding component with a given probability $\gamma$, it is necessary to solve inequality (34) or (36) with respect to $n_{0}$.

\section{Conclusions}

1. Mathematical models of the failures flow of circuit positions with an unlimited number of recoveries (non-instantaneous and finite duration) at different depths of resource recovery are considered. It is shown that the failure flow models with complete or minimal recoveries follow from the model with incomplete recoveries as separate cases. A generalization of the known mathematical models of the failure flow of components with an unlimited number of minimal recoveries of finite duration is obtained.

2. Mathematical models of the failures flow of components of circuit positions with a finite number of recoveries (non-instantaneous and finite duration) of different depth during the assigned service life are considered. The expediency of their use in calculating the residual life of components and functional units of AES is shown

3. The reliability of the developed mathematical models of failure flows of the AES components is confirmed by the correctness of the performed transformations, the coincidence of partial solutions with the known results.

\section{REFERENCES}

1. (1995), Reliability of equipment. Methods for assessing reliability indicators according to experimental data: DSTU 300495, Effective from 1995-01-25, Derzhsprozhyvstandart Ukrainy, Kyiv, 51 p.

2. Bobalo, Yu.Ya., Nedostup, L.A. and Lazko, O.V. (2007), "Analysis of methods for assessing the reliability of systems of compatible components of electronic devices", Radio electronic and computer systems, No 7(26), pp. 212-214.

3. Yurkov, N.K., Kochegarov, I.I. and Petryanin, D.L. (2015), "To the problem of modeling the risk of failure of electronic equipment with long-term functioning", Caspian Journal: Management and High Technologies, No 4(32), pp. $220-231$.

4. Chernyavsky V.M. (2012), "Application of nonparametric methods for assessing the level of reliability of aircraft with low operating intensity", Collection of scientific works of Kharkiv National University of the Air Force, No 3 (32), pp. 59-63.

5. Kuchuk, G., Kovalenko, A., Komari, I.E., Svyrydov, A. and Kharchenko, V. (2019), "Improving big data centers energy efficiency: Traffic based model and method", Studies in Systems, Decision and Control", vol 171, Kharchenko, V., Kondratenko, Y., Kacprzyk, J. (Eds.), Springer Nature Switzerland AG, pp. 161-183, DOI: http://doi.org/10.1007/978-3-030$00253-48$

6. Kuchuk, G., Nechausov, S. and Kharchenko, V. (2015), "Two-stage optimization of resource allocation for hybrid cloud data store", International Conference on Information and Digital Technologies, Zilina, pp. 266-271, DOI: http://dx.doi.org/10.1109/DT.2015.7222982

7. Hudkov M.V. (2010), "Methods of forecasting the reliability of electronic equipment in the operation of aircraft by condition with control parameters", Weapons systems and military equipment, No 4(24), pp. 32-35.

8. Dobrydenko, O.M., Bologin, A.S., Khilchenko, M.F. and Belinska, R.B. (2011), "Modern methods of forecasting the technical condition of aviation equipment", Collection of scientific works of the State Research Institute of Aviation, No 7(14), pp. 163-167.

9. Sviridov, A., Kovalenko, A. and Kuchuk, H. (2018), "The pass-through capacity redevelopment method of net critical section based on improvement ON/OFF models of traffic", Advanced Information Systems, Vol. 2, No. 2, pp. 139-144, DOI: https://doi.org/10.20998/2522-9052.2018.2.24

10. Kovalenko, A. and Kuchuk H. (2018), "Methods for synthesis of informational and technical structures of critical application object's control system", Advanced Information Systems, Vol. 2, No. 1, pp. 22-27, DOI: https://doi.org/10.20998/25229052.2018.1.04

11. Ruban, I., Kuchuk, H. and Kovalenko A. (2017), "Redistribution of base stations load in mobile communication networks", Innovative technologies and scientific solutions for industries, No 1 (1), P. 75-81, doi : https://doi.org/10.30837/25229818.2017.1.075 
12. Donets V., Kuchuk N., Shmatkov S. Development of software of e-learning information system synthesis modeling process. Advanced Information Systems, Vol. 2, No. 2, P. 117-121. DOI: https://doi.org/10.20998/2522-9052.2018.2.20

13. Kashtanov, V.A. and Medvedev, A.I. (2010), "Reliability Theory of Complex Systems", FIZMATLIT, Moscow, 608 p.

14. Bobalo, L.A., Nedostup, Yu.Ya. and Kiselychnyk, M.D. (2013), Quality, reliability of electronic equipment, Lviv Polytechnic Publishing House, Lviv, 196 p.

15. Kozlov, V.A. and Ushakov, I.A. (1985), Handbook for calculating the reliability of radio electronics and automation equipment, Soviet Radio, Moscow, 462 p.

16. Barlow R. and Proshan F. (1985), "Statistical theory of reliability and failure test", Nauka, Moscow, $388 \mathrm{p}$.

17. Gaevsky, S.V., Balakireva, S.M., Komarov, D.V. and Yavtushenko, V.O. (2020), "Analysis of the electronic system of the aircraft as an object of extension of service life", Control, navigation and communication systems, No 1 (59), pp. 15-20.

Received (Надійшла) 23.03.2020

Accepted for publication (Прийнята до друку) 20.05.2020

ABOUT THE AUTHORS / ВідОМОсті ПРО АВТОРІB

Гасвський Сергій В`ячеславович - аспірант кафедри льотної експлуатації, аеродинаміки та динаміки польоту, Льотна академія Національного авіаційного університету, Кропивницький, Україна;

Serhii Haievskyi - graduate student of the Department of Flight Operations, Aerodynamics and Flight Dynamics, Aircraft Academy of the National Aviation University, Kropyvnytskyi, Ukraine;

e-mail: snegovik2207@ukr.net; ORCID ID: http://orcid.org/0000-0003-3434-7494

Хмелевський Сергій Іванович - кандидат технічних наук, доцент, заступник начальника кафедри математичного та програмного забезпечення АСУ, Харківський національний університет Повітряних Сил, Харків, Україна;

Serhii Khmelevskiy - Candidate of technical sciences, Associate Professor, Chair Deputy of mathematical and software ACS department, Ivan Kozhedub Kharkiv National Air Force University, Kharkiv, Ukraine; e-mail: sserg1978@ukr.net; ORCID ID: http://orcid.org/0000-0001-6216-3006

Бойко Артур Васильович - заступник командира частини, військова частина А3544, Кропивницький, Україна; Artur Boiko - deputy commander of the Military unit, Military unit A3544, Kropyvnytskyi, Ukraine; e-mail: arthurbrook1@,gmail.com; ORCID ID: http://orcid.org/0000-0001-1168-9419

Мищенко Тетяна Юріївна - заступник начальника центру, військова частина А2171, Одеса, Україна; Tatiana Mishchenko - deputy head of the center, Military unit A2171, Odesa, Ukraine; e-mail: taniamischenko1992@gmail.com; ORCID ID: http://orcid.org/0000-0001-5131-485X

Тімочко Олександр Олександрович - кандидат технічних наук, інженер з тестування програмних продуктів фірми «Kreditech», Гамбург, Німеччина;

Oleksander Timochko - Expert Quality Assurance Engeneer of Kreditech Holding, Hamburg, Germany; e-mail: $\underline{\text { alexander.timochko@gmail.com; ORCID ID: http://orcid.org/0000-0003-0424-0426. }}$

\section{Математичні моделі потоку відмов комплектуючих виробів радіоелектронної системи літака}

С. В. Гаєвський, С.І. Хмелевський, А. В. Бойко, Т. Ю. Мищенко, О. О. Тімочко

Анотація. Предметом вивчення в статті є процеси функціонування радіоелектронної системи сучасного літака, iï комплектуючих елементів та функціональних вузлів як об'єкта математичного моделювання. Метою є проведення аналізу існуючого математичного апарату, що застосовується для розрахунку потоку відмов та ймовірності безвідмовної роботи радіоелектронної системи літака та можливості його вдосконалення. Завдання: побудувати математичні моделі потоку відмов комплектуючих виробів, функціональних вузлів та радіоелектронної системи літака в цілому 3 необмеженим числом відновлень при різній глибині відновлення ресурсу. Аналізованими методами $\epsilon$ : параметричні методи та імовірнісні методи оцінки безвідмовності роботи. Отримані такі результати. Розроблені математичні моделі потоку відмов схемних позицій радіоелектронної системи літака. Висновки. В результаті розгляду математичних моделей потоку відмов схемних позицій радіоелектронної системи літака отримано узагальнення відомих математичних моделей потоку відмов при необмеженій кількості мінімальних відновлень кінцевої тривалості.

Ключові слова: залишковий ресурс; літак; математична модель; потік відмов; радіоелектронна система; технічний стан; схемна позиція.

\section{Математические модели потока отказов комплектующих изделий радиоэлектронной системы самолета}

С. В. Гаевский, С. І. Хмелевский, А. В. Бойко, Т. Ю. Мищенко, А. А. Тимочко

Аннотация. Предметом изучения в статье являются процессы функционирования радиоэлектронной системы современного самолета, ее комплектующих элементов и функциональных узлов как объекта математического моделирования. Целью является анализ существующего математического аппарата, применяемого для расчета потока отказов и вероятности безотказной работы радиоэлектронной системы самолета и возможности его совершенствования. Задачи: построить математические модели потока отказов комплектующих изделий, функциональных узлов и радиоэлектронной системы самолета в целом с неограниченным числом обновлений при разной глубине восстановления ресурса. Анализируемыми методами являются: параметрические методы и вероятностные методы оценки безотказности работы. Получены следующие результаты. Разработанные математические модели потока отказов схемных позиций радиоэлектронной системы самолета. Выводы. Получено обобщение известных математических моделей потока отказов комплектующих изделий при неограниченном количестве минимальных обновлений конечной длительности.

Ключевые слова: остаточный ресурс; самолет; математическая модель; поток отказов; радиоэлектронная система; техническое состояние; схемная позиция. 